\title{
JURISDICCIÓN VOLUNTARIA, CONCILIACIÓN Y MEDIACIÓN: NOTAS PARA SU DELIMITACIÓN DOGMÁTICA*
}

\author{
Juan Ramón LIÉBANA ORTIZ \\ ABOGADO \\ PROFESOR DE DERECHO PROCESAL \\ UNIVERSIDAD DE LA RIOJA
}

SUMARIO: I. Introducción. II. Los expedientes de jurisdicción voluntaria en materia de Derecho procesal. II.I. De las diligencias preliminares civiles y de los actos preparatorios laborales. II.2. De la habilitación para comparecer en juicio y del nombramiento del defensor judicial. II.3. De las informaciones para perpetua memoria. II.4. De la conciliación penal. III. La conciliación previa al proceso. IV. La mediación. V. Conciliación, mediación y jurisdicción voluntaria. VI. Valoración de algunas novedades en materia de conciliación y mediación. VI.I. Profesionales competentes para conocer de la conciliación y la mediación. VI.2 Eficacia de las resoluciones de conciliación y mediación.

RESUMEN: En el presente trabajo analizaremos las razones por las que consideramos que ni el acto de conciliación ni la mediación deben ser reputadas uno de los expedientes de jurisdicción voluntaria en materia de Derecho procesal, para concluir con un análisis crítico de dos de las principales novedades introducidas en el procedimiento de conciliación civil previa y las propuestas en materia de mediación.

PALABRAS ClAVE: Jurisdicción voluntaria, conciliación, mediación, sistema complementario de Administración de Justicia.

\section{VOLUNTARY JURISDICTION, CONCILIATION AND MEDIATION: NOTES FOR DOGMATIC DELIMITATION}

ABSTRACT: In this paper we examine the reasons why we consider that the neither the conciliation conference nor the mediation ought to be recognized as a voluntary jurisdiction proceeding to end up with a critical analysis of the two major innovations introduced in the civil previous conciliation act and those proposed for the mediation.

KEYWORDS: Voluntary jurisdiction, conciliation, mediation, alternative dispute resolution.

\footnotetext{
* El presente trabajo, que se incardina dentro del Proyecto de Investigación «Instrumentos de justicia restaurativa en el proceso penal español: hacia una regulación de la mediación penal», financiado por el Ministerio de Ciencia e Innovación (DER 2008-03547), supone una reelaboración del capítulo octavo de la Tesis Doctoral que, con el título La jurisdicción voluntaria: concepto y régimen jurídico, el autor defendió el pasado 29 de junio de 2OII bajo la dirección de los Profesores Doctores GARCIANDÍA GonZÁlEZ y VeGas TorRes y que obtuvo la máxima calificación por unanimidad del Tribunal, compuesto por los Profesores Doctores BonET NAVARRO, Cordón Moreno, Muerza Esparza, Calderón Cuadrado y Cedeño Hernán.
} 


\section{Introducción}

De acuerdo con la relación jurídica objeto del expediente, y siguiendo lo previsto en la Ley de Enjuiciamiento Civil (en adelante LEC) de I88I, tradicionalmente se ha realizado una clasificación dual de los expedientes de jurisdicción voluntaria, agrupándolos en función de la materia sobre la que versan en Derecho civil y en Derecho mercantil. Sin embargo, dicha clasificación resulta poco ambiciosa $y$, si tenemos en cuenta el ordenamiento jurídico en su conjunto, es posible realizar una clasificación más amplia para incluir expedientes relativos a otras materias. En este sentido, en nuestra opinión, en atención a la naturaleza de la relación jurídica, pueden diferenciarse los expedientes de jurisdicción voluntaria en materia de Derecho civil y mercantil, pero también en materia de Derecho procesal. Entre estos últimos se incluyen, por ejemplo: las habilitaciones para comparecer en juicio (arts. I994 a 200I LEC/I88I); el nombramiento de defensor judicial (arts. I63 y 299 a $302 \mathrm{CC}$ ); las informaciones para perpetua memoria (arts. 2002 a 2010 LEC/I88I); la conciliación civil (arts. 460 a 480 LEC/I88I); las diligencias preliminares (arts. 256 a 263 LEC); la conciliación laboral previa (arts. 63 a 68 LPL); los actos preparatorios del proceso laboral declarativo (arts. 76 y 77 LPL); y la conciliación penal en los procesos por injuria y calumnia contra particulares (art. 804 LECrim).

Pues bien, dicho lo anterior, en el presente trabajo analizamos las razones por las que consideramos que ni el acto de conciliación ni la mediación deben ser reputados expedientes de jurisdicción voluntaria en materia de Derecho procesal, para concluir con un análisis crítico de algunas de las novedades introducidas en el procedimiento de conciliación civil previa (arts. 460 a 480 LEC/I88I) tras las reformas operadas por el art. I de la Ley 13/2009, de 3 de noviembre, de reforma de la legislación procesal para la implantación de la nueva Oficina Judicial, así como de las novedades propuestas en materia de mediación por el Proyecto de Ley de Mediación en Asuntos Civiles y Mercantiles de 20II (en adelante PLMed) ${ }^{\mathrm{r}}$. Ello no obsta, sin embargo, para que con carácter previo llevemos a cabo un sucinto análisis de la naturaleza jurídica de los demás expedientes de Derecho procesal que, según se ha reputado tradicionalmente, pertenecen a la llamada jurisdicción voluntaria.

\section{Los expedientes de jurisdicción voluntaria en materia de Derecho procesal}

Antes de reflexionar sobre la caracterización dogmática de la conciliación y la mediación, resulta necesario realizar unas breves consideraciones en torno a la naturaleza jurídica de los actos preparatorios del proceso laboral declarativo, la conciliación penal, la habilitación para comparecer en juicio, el nombramiento del defensor judicial, las diligencias preliminares y, por último, las informaciones para perpetua memoria. Dicha digresión no resulta baladí sino que, muy al contrario, atiende a la necesidad de delimitar adecuadamente el concreto ámbito dogmático de los expedientes de jurisdicción voluntaria en materia de Derecho procesal.

II.I. De las diligencias preliminares civiles y de los actos preparatorios laborales.

Aunque cierto sector doctrinal ha mantenido la naturaleza contenciosa de las diligencias preliminares ${ }^{2}$, la doctrina mayoritaria considera que constituyen expedientes de

\footnotetext{
${ }^{\mathrm{I}}$ Cfr. Boletín Oficial de las Cortes Generales, Congreso de los Diputados, IX Legislatura, Serie A: Proyectos de Ley, referencia I2I/O00I22, núm. I22-I, de 29 de abril, pp. I-I2.

${ }^{2}$ Vid., sin ánimo de exhaustividad, Banacloche Palao, J., Las diligencias preliminares, Ed. Civitas, Pamplona 2003, pp. 32-33; y, con el código procesal civil anterior, ÁlvAREZ AlARCón, A., Las diligencias preliminares en el
} 
jurisdicción voluntaria ${ }^{3}$. En este sentido, estamos de acuerdo con DíEZ-PICAZO GIMÉNEZ en que en las diligencias preliminares se realiza una actividad judicial no jurisdiccional, facultativa y de preparación del proceso, que tiene por objeto averiguar hechos relevantes ${ }^{4}$ (información acerca de circunstancias relativas a la personalidad del futuro demandado, otros extremos que quien pretenda presentar una demanda precise conocer, así como obtener documentos $\mathrm{u}$ objetos que resulten necesarios para el futuro proceso) y que carece de ejecutabilidad 5 . Tras la práctica de las diligencias preliminares el Juez no dicta una resolución judicial que decide una controversia entre partes sino que, por el contrario, el órgano judicial documenta los extremos que un sujeto solicita a través de un procedimiento de jurisdicción voluntaria; a los efectos, eso sí, de la posible incoación de un futuro proceso $^{6}$. Adviértase que, como es sabido, en la actualidad las diligencias preliminares se encuentran reguladas en los arts. 256 a 263 LEC ya que por razones prácticas el legislador no consideró adecuado posponer su nueva regulación a la futura aprobación de una ley de jurisdicción voluntaria (Disposición Final $18^{\mathrm{a}}$ LEC), a fuerza de perpetuar la crónica dispersión normativa en esta materia7.

Por su parte, como bien ha sostenido la doctrina laboralista respecto de la legislación anterior, y resulta perfectamente aplicable a la regulación vigente, respecto de los actos preparatorios del proceso laboral declarativo (arts. 76 y 77 de la Ley $36 / 20$ II, de io de octubre, reguladora de la Jurisdicción Social [en adelante LJS]) «no se trata propiamente de procesos, pues el órgano judicial no actúa en ellos jurisdiccionalmente, sino que se trata de actos de jurisdicción voluntaria que el futuro demandante puede o no solicitar, según estime conveniente» ${ }^{8}$. Reconociendo la pertenencia de los actos preparatorios del proceso

proceso civil, J. M. Bosch Editor, Barcelona I997, pp. 50 y ss. y GuasP Delgado, J., Comentarios a la Ley de Enjuiciamiento Civil, T. II, Vol. I, Aguilar, Madrid I945, p. I52.

3 Cfr., por todos, Garciandía González, P. M., en Comentarios a la Ley de Enjuiciamiento Civil (coord. Cordón Moreno, F., Armenta Deu, T., Muerza Esparza, J. J., y Tapia Fernández, I.), Volumen I, Ed. Aranzadi, Pamplona 200I, p. 949; Diez-Picazo Giménez, I., Derecho Procesal Civil (con De la Oliva Santos, A.), cit., p. 257; Montero Aroca, J. (con Gómez Colomer, J. L., Montón Redondo, A. y Barona Vilar, S.), Derecho jurisdiccional II, $\mathrm{I}^{\mathrm{a}}$ ed., Tirant lo Blanch, Valencia 2003, p. I54.

${ }^{4}$ Cfr. Diez-Picazo Giménez, I. (con De la Oliva Santos, A.), Derecho Procesal Civil. El proceso de declaración, CERA, $3^{\text {a }}$ ed., Madrid 2004, p. 256.

${ }^{5}$ En este sentido se ha pronunciado el Tribunal Supremo, por ejemplo, en su Sentencia de 20 de junio de I986 (RJ I986\3784) en la que sostiene que «la doctrina más autorizada concibe las diligencias preliminares, reguladas en los arts. 497 y siguientes [de la LEC/I88I] como un conjunto de actuaciones judiciales que se dirigen a aclarar las cuestiones que pudieran surgir antes del nacimiento de un proceso principal, por lo que este proceso aclaratorio carece de ejecutabilidad» $\left(\mathrm{FJ} \mathrm{I}^{\circ}\right)$, y respecto de la vigente LEC, en el Auto de II de noviembre de 2002 (RJ 2003\575), que lo reitera.

${ }^{6}$ En nuestra opinión, resulta desacertada la postura mantenida al respecto por el Tribunal Supremo que, en su Auto de II de noviembre de 2002 (RJ 2003\575), estableció que «pueden considerarse las diligencias preliminares como el conjunto de actuaciones de carácter jurisdiccional por las que se pide al Juzgado de Primera Instancia competente la práctica de concretas actuaciones para resolver los datos indispensables para que el futuro juicio pueda tener eficacia» (F.J. $2^{\circ}$ ); habiendo sido seguido, además, por AAP de Madrid de 20 de septiembre de 2010 (JUR20II\I8689); AAP de Guadalajara de 2 de febrero de 2007 (JUR 2007\I33I42); AAP de Almería de 23 de marzo de 2006 (AC 2006\995), entre otras

${ }^{7}$ En este sentido, durante la tramitación parlamentaria del Proyecto de Ley de Jurisdicción Voluntaria, el Grupo Popular en el Congreso de los Diputados presentó las enmiendas números. 24I y 242 con el objeto de introducir en dicho texto normativo un nuevo Título, con ocho artículos, dedicado a las diligencias preliminares. Sin embargo, esta propuesta fue finalmente desestimada por entenderse que la regulación que de estas diligencias se contiene en la LEC es suficientemente moderna y operativa y que, por tanto, no precisa modificarse, aun a pesar de que, de haberse aprobado el mencionado proyecto de ley, éstas hubieran quedado fuera de la legislación reguladora de la jurisdicción voluntaria, a la que sin duda pertenecen, perpetuándose la dispersión normativa actualmente vigente en esta materia.

${ }^{8}$ Cfr., por todos, Monereo Pérez, J. L., Molina Navarrete, C., Moreno Vida, M. N., Olarte Encabo, S. y FernÁndeZ Avilés, J. A., Manual de Derecho procesal del trabajo, $2^{\mathrm{a}}$ ed., Tecnos, Madrid 20Io, p. I6o. En igual sentido se ha pronunciado también, MonTERo ArocA, J. (Introducción al proceso laboral, $5^{\mathrm{a}}$ ed., Bosch, Barcelona 2000, pp. I38-I39) sosteniendo que «en la LEC los arts. 256 a 263 regulan un conjunto heterogéneo de las que suelen denominarse diligencias preliminares, que son actos de jurisdicción voluntaria (no procesos) que el futuro demandante puede o no instar según lo estime conveniente (...) De ese conjunto de diligencias 
laboral a los expedientes de jurisdicción voluntaria, en referencia al art. 76.I de la legislación anterior, MONTERO AROCA sostiene que «en la LPL no se dice cómo se procederá procedimentalmente, por lo que deberá estarse a los arts. 258 a 26I.I LEC, teniendo en cuenta que la declaración será oral y con juramento (o promesa)»9 . A igual conclusión cabe llegar de la interpretación de la nueva regulación introducida para los actos preparatorios del proceso laboral en 20II. Tampoco en el art. 76.I LJS se establece un procedimiento ad hoc para que el órgano judicial obligue a quien vaya a resultar demandado a que «preste declaración acerca de algún hecho relativo a la personalidad, capacidad, representación o legitimación de éste; o para que con igual finalidad aporte algún documento, cuyo conocimiento sea necesario para el juicio»; o para que el órgano judicial proceda a realizar «la determinación de quiénes son los socios, partícipes, miembros o gestores de una entidad sin personalidad y las diligencias necesarias encaminadas a la determinación del empresario y los integrantes del grupo o unidad empresarial, así como la determinación de las personas concurrentes a la producción de un daño con la persona a la que se pretenda demandar y la cobertura del riesgo en su caso». Por lo tanto, atendida la pertenencia de los actos preparatorios del proceso laboral a la jurisdicción voluntaria, debe aplicarse supletoriamente el procedimiento previsto al respecto en los arts. 258 a 26I.I LEC (arg. ex Disposición Final cuarta LJS). En igual sentido se pronunciaban AlBIOL MONTESINOS, Alfonso Mellado, Blasco Pellicer, y Goerlich PeSET, al mantener la aplicación del art. 256 LEC respecto de la viabilidad de otras diligencias preliminares no previstas en los arts. 76 y 77 LPL -a saber: declaración del futuro demandado y examen de documentos, respectivamente- $y$, de manera subsidiaria, en cuanto al procedimiento y la forma de adoptar las resoluciones ${ }^{\mathrm{IO}}$. La nueva LJS viene a reconocer expresamente esta posibilidad apuntada por la doctrina laboralista en su art. 76.3, al establecer que: «podrá formularse también petición de práctica de otras diligencias y averiguaciones necesarias para preparar el juicio de las previstas en el art. 256 LEC».

De todo lo expuesto, puede concluirse entonces fundadamente que tanto las diligencias preliminares civiles (arts. 256 a 263 LEC) como los actos preparatorios del proceso laboral declarativo (arts. 76 y 77 LJS) deben incluirse entre los expedientes de jurisdicción voluntaria en materia de Derecho procesal.

II.2 De la habilitación para comparecer en juicio y del nombramiento del defensor judicial

Como es sabido la habilitación para comparecer en juicio es un mecanismo para suplir la falta de capacidad procesal que impide la comparecencia en éste. Además, la ratio legis del nombramiento del defensor judicial consiste en integrar la capacidad procesal de los hijos menores de edad no emancipados, o de los incapacitados que tengan intereses contrapuestos a los de sus padres; configurándose aquél como un órgano eventual e intermitente de representación y amparo de los menores e incapacitados de acuerdo con los arts. 7.2 y 8 LEC. Pues bien, en nuestra opinión se trata de un expediente de jurisdicción voluntaria de naturaleza constitutiva, dirigido a suplir la falta de capacidad procesal en determinados supuestos, precisamente porque carece de una parte contrapuesta. A priori nadie se opondrá a que un menor o incapacitado pueda ser habilitado para comparecer o ser representado en juicio. La controversia se verificará en la justa liza que tenga lugar

preliminares la LPL ha asumido sólo dos y las ha llamado 'actos preparatorios', regulándolos en los arts. 76.I y 77». Debe recordarse, igualmente, que la Sección I del Capítulo I del Título I del Libro II de la Ley de la Jurisdicción Social, encargada de regular los arts. 76 y 77 objeto de comentario, ha ampliado su título para pasar a denominarse «Sección I. Actos preparatorios $y$ diligencias preliminares».

9 Vid. Montero Aroca, J., Introducción al proceso laboral, cit., p. I39.

io Albiol Montesinos, I., Alfonso Mellado, C. L., Blasco Pellicer, A. y Goerlich Peset, J. M. Derecho procesal laboral, $7^{\mathrm{a}}$ ed., Tirant lo Blanch, Valencia 2007, p. I5I. 
posteriormente en sede jurisdiccional, en la que los intereses del menor o incapaz estarán adecuadamente tutelados por el defensor judicial.

Por lo que respecta a su regulación procesal, cabe recordar que los arts. 45 a 50 del Proyecto de Ley de Jurisdicción Voluntaria de 2007 (en adelante PLJV) ${ }^{\mathrm{II}}$ configuraban ex novo un expediente que suponía la fusión del vigente procedimiento de las habilitaciones para comparecer en juicio de los arts. I994 a 200I LEC/I88I -que sólo resulta aplicable cuando los padres del menor estén ausentes por ignorarse su paradero o bien cuando éstos se negaren a representar en juicio al hijo (arg. ex art. I995 LEC/I88I)- con el expediente innominado contenido en el art. $300 \mathrm{CC}$-aplicable a todos los supuestos en que exista conflicto entre los intereses del menor y los de sus padres-. Esta innovación hubiera sido muy bienvenida a los efectos de dotar de coherencia interna a una parcela del ordenamiento jurídico que carece de ella y que, por tanto, resulta de oscura interpretación.

\section{II.3 De las informaciones para perpetua memoria}

El procedimiento de las informaciones para perpetua memoria tiene por objeto la documentación judicial de unas declaraciones de testigos sobre hechos que interesan al solicitante y no son susceptibles de perjudicar a tercero. Como se puede observar, se trata de un expediente en que el interesado solicita al órgano judicial que dé «fijeza y permanencia a una declaración testifical variable y temporal. Mediante la intervención judicial se garantiza en la medida de lo posible que la documentación el testimonio sea lo más perfecta posible» ${ }^{\text {I2 }}$. Es por esta razón que PRIETO-CASTRO Y FERRÁNDIZ consideraba este expediente de contenido probatorio en sentido lato ${ }^{\mathrm{I3}}$.

Puesto que se trata de una solicitud en la que el interesado insta al órgano judicial para que documente una declaración testifical que no perjudica a nadie y, por tanto, nadie se opone a ella -con independencia de que dicha información ad perpetuam pueda ser utilizada y discutida en un proceso ulterior ${ }^{14}$-, dogmáticamente se configura como un procedimiento de jurisdicción voluntaria. Ahora bien, dada la complicación y lentitud de sus trámites, nuestro ordenamiento se proveyó de nuevos cauces para cumplir la misma finalidad documentadora, hasta el punto de que «en la actualidad, con finalidades muchas veces concurrentes, pueden utilizarse nada menos que cinco procedimientos» ${ }^{15}$-entre los que destacan las actas de notoriedad y las actas de presencia, que cumplen también una función de preconstitución de pruebas-. De esta forma, en la actualidad las informaciones para perpetua memoria han caído en el más absoluto desuso y su regulación procedimental resulta totalmente innecesaria. Sin embargo, el razonable pronóstico que hiciera en ig 63 SERRA DOMINGUEZ, vaticinando la supresión del citado procedimiento de jurisdicción voluntaria en una próxima reforma de nuestra leyes por su desaparición en la práctica de

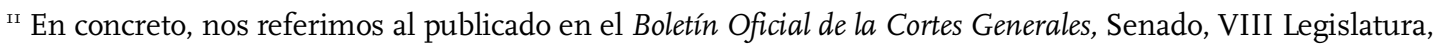
Serie II: Proyectos de Ley, referencia núm. II5 (a), de 24 de julio de 2007, pp. I-59.

${ }^{12}$ Cfr. Serra Domínguez, M., «Informaciones para perpetua memoria», en Serra Domínguez, M., Estudios de Derecho procesal, Ariel, Barcelona I969, p. 65I.

I3 Vid. Prieto-Castro y Ferrándiz, L., Derecho concursal, procedimientos sucesorios, jurisdicción voluntaria, medidas cautelares, Tecnos, Madrid i974, p. I88.

${ }^{14}$ En este sentido SERRA Domínguez, M. («Informaciones para perpetua memoria», cit., p. 65I) concluye: «tal documentación tendrá principalmente valor al plantearse un proceso en el que los hechos testimoniados tengan real importante. Pero independientemente de ello puede servir para evitar el proceso o simplemente para utilizarla como prueba extraprocesal».

is Cfr. GonzÁlez PovedA, B., La jurisdicción voluntaria, Thomson-Aranzadi, 4ª ed., Cizur Menor 2008, p. 220. 
los tribunales ${ }^{16}$, todavía no se ha llevado a efecto, a pesar de las muchas oportunidades que el legislador ha tenido desde entonces; la última en el año 2009.

\section{II.4. De la conciliación penal}

Tal y como establece el art. 804 LECrim, la conciliación penal previa al juicio está circunscrita exclusivamente a los procesos por injuria y calumnia contra particulares. Dicha circunscripción resulta del todo punto razonable pues, tratándose de delitos privados -de hecho, los únicos regulados en nuestro Código Penal- y pudiendo el querellante disponer sobre el objeto del proceso penal, el legislador decimonónico estableció un mecanismo autocompositivo para la resolución privada de la controversia como una vía in extremis para evitar el proceso penal.

Ahora bien, la conciliación penal carece de un procedimiento ad hoc ya que el mencionado art. 804 LECrim prescribe simplemente la obligación de las partes de acudir al acto de conciliación con carácter previo al inicio del proceso. Es jurisprudencia consolidada del Tribunal Supremo la aplicación en esta materia del procedimiento previsto para la conciliación civil en los arts. 460 a 480 LEC/I88I al campo penal ${ }^{17}$. En este sentido, estamos de acuerdo con CORTÉs DOMínGUEZ, GIMENO SENDRA y MORENO CATENA cuando sostienen que: «la sustanciación del acto de conciliación, que produce efectos suspensivos respecto al plazo de prescripción del delito durante dos meses desde su presentación (art. 479 LEC[/I88I]), se acomodará a las prescripciones de los arts. 460 a 480 de la LEC/I88I $\gg^{18}$.

Con todo, debe hacerse notar que existe una diferencia de procedimiento entre la conciliación civil (art. 460 LEC/I88I) y la conciliación penal (art. 804 LECrim), puesto que mientras la primera es facultativa para los interesados, la celebración de la segunda es preceptiva si se quiere interponer una querella por injurias o calumnias. La obligatoriedad de la celebración de la conciliación penal no se debe atribuir a una suerte de descuido del legislador que, al igual que ya hiciera con la conciliación civil del art. 460 LEC/I88I -que, recordemos, también debía celebrarse con carácter preceptivo hasta su modificación mediante Ley 34/I984, de 6 de agosto, de reforma urgente de la LEC/I88I-, ha podido modificar dicha preceptividad en innumerables ocasiones; últimamente, incluso, con la Ley 13/2009, de 3 de noviembre, de reforma de la legislación procesal para la implantación de la nueva Oficina judicial, que, entre otros, ha modificado los arts. 808 y 8I5 LECrim del mismo procedimiento por delitos de injuria y calumnia contra particulares. Igualmente la Ley 37/20II, de io de octubre, de medidas de agilización procesal podría haber derogado la preceptividad de la conciliación penal previa a la querella por calumnias o injurias, contribuyendo con ello a la agilización en la tramitación procedimental de este proceso penal especial.

Teniendo en cuenta que nos hallamos ente delitos cuyos bienes jurídicos protegidos pertenecen a la esfera del honor, la fama y la buena reputación de las personas, consideramos que la obligatoriedad de la celebración de la conciliación penal con carácter previo a la interposición de querella por un delito de injuria o calumnia contra particulares tipificado en los arts. 205 a 2I6 CP obedece solamente a una razón: tratar de evitar la excesiva onerosidad que representa el proceso penal para el querellado ${ }^{\mathrm{I}}$. Resulta forzoso

\footnotetext{
${ }^{16}$ Vid. Serra DomíngueZ, M., «Informaciones para perpetua memoria», cit., p. 652.

${ }^{17}$ Cfr., por todas, las SSTS de 25 de mayo de I977 (RJ I977\2448) y de I8 de marzo de I992 (RJ I992\2368).

${ }^{18}$ Vid. Cortés Domínguez, V., Gimeno Sendra, V. y Moreno Catena, V., Derecho procesal penal, $3^{\mathrm{a}}$ ed., Colex, Madrid I999, p. 934.

I9 Dicha onerosidad se pone de manifiesto, especialmente en el delito de calumnias, cuando el querellado es un representante político o un cargo público puesto que en ocasiones la utilización torticera de este tipo penal
} 
concluir entonces que la configuración dogmática de la conciliación penal que examinamos debe ser idéntica a la que se realice de la conciliación civil previa al proceso en el epígrafe siguiente. Las reflexiones críticas que hagamos sobre el acto de conciliación civil son perfectamente aplicables a la presente conciliación penal, más cuando las especialidades procesales civiles resultan de aplicación en el campo penal para colmar la laguna jurídica de la que adolece el art. 804 LECrim de conformidad con el carácter supletorio de la LEC (art. 4).

En otro orden de cosas, aunque carecemos de datos estadísticos que lo refrenden, entendemos que, al igual que sucedía con la conciliación civil, en la mayoría de los casos el acto de conciliación penal resulta inútil, especialmente en lo referente a las injurias ${ }^{2 \circ}$. Si a ello unimos que la tutela al honor se hizo más débil con la promulgación del vigente Código Penal al reducirse la intensidad de las penas (pasando éstas de las privativas de libertad previstas en el Código Penal de I973 a las penas de multa recogidas en el vigente art. 209 $\mathrm{CP}$ ), parecería acertado que el legislador derogara el delito de injurias, ya que la protección legal del derecho al honor encuentra mejor acomodo en el vía civil (Ley Orgánica I/I982, de 5 de mayo, de Protección Civil del Derecho al Honor, a la Intimidad Personal y Familiar y a la Propia Imagen). De este modo, la conciliación prevista en el art. 804 LECrim dejaría de aplicarse a las injurias, cuya tutela judicial quedaría enclavada en el ámbito civil y, en lo que a la conciliación previa se refiere, se regiría directamente por lo previsto en los arts. 460 y SS. LEC.

\section{La conciliación previa al proceso}

Como ya ha quedado expuesto, antes de que el actor presente su demanda ante el órgano jurisdiccional se pueden realizar ciertas actividades previas tendentes a la preparación del proceso, ya sea éste civil o laboral: las diligencias preliminares o actos preparatorios y el acto de conciliación previa, entre otras ${ }^{2 \mathrm{I}}$.

Respecto de lo civil, DiEZ-PICAZO GIMÉNEZ sostiene que «es común a todas estas actividades previas al proceso que en ellas no se ejerce jurisdicción, no son actividades propiamente jurisdiccionales (...) Y en las diligencias preliminares y el acto de conciliación porque aunque son actividades judiciales, es decir, se realizan por y ante un tribunal, no tienen naturaleza jurisdiccional, es decir, se engloban dentro de la llamada jurisdicción voluntaria o, lo que es lo mismo, se trata de actividades encomendadas a los órganos judiciales donde no existe una verdadera controversia entre las partes $»^{22}$.

La doctrina mayoritaria y la jurisprudencia han entendido que la conciliación es un expediente de jurisdicción voluntaria, y no un proceso, debido sustancialmente a que en ella

lleva aparejada la llamada pena de banquillo, que resulta mucho más gravosa por su impacto mediático y la posible mella en la trayectoria pública o profesional del querellado, incluso cuando, intentada la conciliación sin éxito, el Juez la archiva tras la fase de instrucción previa a la apertura de juicio oral.

${ }^{2 \circ}$ Piénsese, por ejemplo, en la multitud de tertulianos y personajes públicos de la prensa del corazón que día sí y día también se querellan por injurias en nuestro País y hacen uso de este recurso jurídico. Lo que estas personas buscan recurriendo a la protección penal del honor es una mayor notoriedad pública a la vez que unos ingresos pecuniarios extras.

${ }^{21}$ Debe recordarse, igualmente, que, de conformidad con los arts. I20 a I26 de la Ley 30/1992, de 26 de noviembre, de Régimen Jurídico de las Administraciones Públicas y del Procedimiento Administrativo Común, nuestro Ordenamiento Jurídico concede a las Administraciones Públicas, en su consideración de potentior personae, el privilegio de que, antes de entablar una demanda contra ellas ante los tribunales civiles o laborales (vid. asimismo arts. 69 a 73 del Real Decreto Legislativo 2/I995, de 7 de abril, por el que se aprueba el Texto Refundido de la Ley de Procedimiento Laboral) es necesario, como regla general, haber formulado previamente una reclamación administrativa con el fin de permitirles eludir, en su caso, los litigios antes de ser demandadas ante los tribunales.

${ }^{22}$ Cfr. Diez-Picazo Giménez, I. (con De la Oliva Santos, A.), Derecho Procesal Civil, cit., p. 226. 
falta la demanda, la postulación del juicio y la sentencia ${ }^{23}$. De hecho, en el año 2000 el legislador entendió que se trataba de un procedimiento de dicha naturaleza jurídica, ya que mantuvo vigente en esta materia los arts. 460 a 480 LEC/I88I hasta la promulgación de su ley reguladora. Sin embargo, no faltan autores que conciben la conciliación como un verdadero proceso ${ }^{24}$ o que la asimilan a la jurisdicción ${ }^{25}$. Aunque consideramos que la conciliación carece de carácter jurisdiccional, precisamente porque falta en ella la demanda, la postulación de un juicio y la sentencia, sin embargo, en nuestra opinión dicha actividad preprocesal tampoco puede considerarse un expediente más de jurisdicción voluntaria, puesto que en ella se verifica una controversia.

En efecto, siguiendo a MONTERO AROCA, la conciliación puede ser definida como «la comparecencia necesaria o facultativa de las partes en un conflicto de intereses, ante una autoridad designada por el Estado, para que en su presencia traten de solucionar el conflicto que las separa, regulada por el ordenamiento jurídico que atribuye determinados efectos, asimismo jurídicos, a lo en ella convenido» ${ }^{26}$. De este modo, al verificarse en su seno un conflicto de intereses, el acto de conciliación se aparta de la caracterización dogmática de los expedientes de jurisdicción voluntaria.

Ahora bien, a pesar de existir dicho conflicto de intereses jurídicos entre las partes, la conciliación se basa precisamente en la no confrontación; es decir, en que la resolución de la disputa se produzca a través del acuerdo de las partes. Por ello, se puede conceptuar como un método de resolución de controversias preprocesal ${ }^{27}$, auto-compositivo y no adversativo.

Aún a pesar de que el acto de conciliación está integrado funcionalmente en un sistema de solución de conflictos de carácter público administrado por órganos estatales, cuales son los Secretarios Judiciales, debe destacarse su componente privado en cuanto a que la gestión y tramitación del conflicto surgido de un determinado negocio jurídico está a cargo de las propias partes. Considerado el negocio jurídico como un acto de autonomía privada que reglamenta para sus autores una relación o situación jurídica que tiende a

${ }^{23}$ Así lo han sostenido, por todos, CAlAmandreI, P., Instituciones de Derecho procesal civil (trad. SENTIS Melendo, S.), Vol. II, EJEA, Buenos Aires i986 p. I98; Gómez Orbaneja, E. y Herce Quemada, V., Derecho Procesal Civil, Tomo II, Artes Gráficas y Ediciones, 6a ed., Madrid ig69, pp. I98-ig9; MoReno CATENA, V. (con Cortés Domínguez, V. y Gimeno Sendra, V.), Derecho Procesal Civil, $3^{a}$ ed., Colex, Madrid 2000, p. I64; DiezPicazo Giménez, I. (con De la Oliva Santos, A.), Derecho Procesal Civil, cit., p. 226; y Montero Aroca, J. (con Gómez Colomer, J. L., Montón Redondo, A. y Barona Vilar, S.), Derecho Jurisdiccional II, cit., p. I46. Esta postura fue asumida también por el Tribunal Supremo en sus Sentencias de 5 de noviembre de I976 (RJ I976 44585 ) y de 3I de octubre de I989 (RJ I989\7040). En el mismo sentido vid., más modernamente, SSAP de Granada de I2 de enero de 2004 (JUR 2004\IO7OI7) y de Barcelona de I9 de mayo de 2005 (JUR 2005\I73338).

${ }^{24}$ Nos referimos a GuAsp Delgado, J. (Comentarios..., T. II, Vol. I, cit., pp. 9-IO), quien define la conciliación como un tipo especial de proceso cuya pretensión se dirige a obtener del Juez una actividad conciliadora o de avenencia entre el sujeto activo y el sujeto pasivo de la solicitud que se formula.

${ }^{25}$ En concreto, un sector doctrinal italiano (vid. MorTARA, L., Commentario del codice e delle leggi di procedura civile, Vol. III, Ed. Villardi, Milano I923, p. 356; SATTA, S., «Dalla conciliazione alla giurisdizione», en Rivista di Diritto Processuale Civile, núm. I (I939), pp. 22I-222; CARnelutTI, F., «Diritto e processo», en IdEM, Trattato del processo civile, Napoli I958, p. 283) considera que Jurisdicción y conciliación tienen en común tanto el punto de partida, como el resultado y el modo de desarrollarse. Sin embargo, la Corte Constitucional italiana, en su Sentencia $276 / 2000$, ha juzgado pertinente sostener que la conciliación carece de carácter jurisdiccional, suponiendo por el contrario una función administrativa.

${ }^{26}$ Cfr. Montero Aroca, J., Derecho Jurisdiccional II (con Gómez Colomer, J. L., Montón Redondo, A. y BARONA Vilar, S.), cit., pp. I45-I46.

${ }^{27}$ Así lo han sostenido igualmente, respecto de la conciliación laboral, tanto Albiol MonTESinos, I., AlFONSO Mellado, C. L., Blasco Pellicer, A. y Goerlich Peset, J. M., Derecho procesal laboral, cit., p. I33, como Monereo Pérez, J. L., Molina Navarrete, C., Moreno Vida, M. N., Olarte EnCAbo, S. y Fernández Avilés, J. A., Manual de Derecho procesal del trabajo, cit., p. I34. Estos últimos autores sentencian que la conciliación laboral previa, regulada en los arts. 63 a $68 \mathrm{LPL}$, «constituye una manifestación de la preferencia en el ordenamiento laboral por los mecanismos de solución extrajudicial de conflictos, de manera que, incluso para acudir al procedimiento judicial de solución, se exige previamente -al menos- el intento de la conciliación extraprocesal». 
producir efectos jurídicos, consistente en la adquisición, modificación o extinción de un derecho subjetivo ${ }^{28}$, cuando se produce un conflicto entre ellos, pueden optar por acudir a la conciliación para solventarlo de común acuerdo aconsejados por un tercero.

En definitiva, el acto de conciliación, en nuestro criterio, no pertenece a la jurisdicción voluntaria -en aquél se verifica una controversia entre las partes cuya ausencia es presupuesto necesario de ésta-, sino que se trata de un sistema auto-compositivo contractual de resolución de controversias, alternativo a la vía jurisdiccional y que, por ley, queda encomendado al órgano judicial (arg. ex arts. II7.4 CE, 2.2 y 456.3.c LOPJ y 460 LEC/I88I $)^{29}$, llamado a aconsejar inter partes en la búsqueda de una solución que evite el proceso ${ }^{30}$.

\section{La mediación}

La mediación puede ser definida como un «sistema de resolución de conflictos, en el cual un tercero se interpone entre los contendientes procurando su reconciliación mediante su asistencia en la obtención de un acuerdo» ${ }^{3 \mathrm{I}}$ o, según el art. I PLMed, como «aquel medio de solución de controversias en que dos o más partes en conflicto intentan voluntariamente alcanzar por sí mismas un acuerdo para su resolución con la intervención de un mediador» ${ }^{32}$. De esta forma, siguiendo a MARTín DIZ, se puede caracterizar a la mediación como un sistema o método de solución de conflictos autocompositivo, no adversativo, complementario a la jurisdicción, extrajudicial y alternativo, también dotado por un componente privado por cuanto son las partes quienes por sí mismas y de forma

${ }^{28}$ Cabe recordar, a este respecto, la definición de negocio jurídico sostenida por DE CASTRO y Bravo, F. (El negocio jurídico, INEJ, Madrid I97I, p. 34): «pudiera concluirse que el Derecho considera como negocio jurídico: 'la declaración do acuerdo de voluntades, con que los particulares se propone conseguir un resultado, que el Derecho estima digno de su especial tutela, sea en base sólo a dicha declaración o acuerdo, sea completado con otros hechos o actos'». Para un pausado estudio del negocio jurídico, vid. Flume, W., El negocio jurídico (trad. de Miquel González, J. M. y Gómez Calle, E.), Fundación Cultural del Notariado, Madrid i998, passim, especialmente pp. 48-49.

${ }^{29}$ Cabe recordar a este respecto que hasta mayo de 2010 el conocimiento del acto de conciliación estaba atribuido a los Jueces de Primera Instancia o de Paz pero, con la reforma de la legislación procesal para la implantación de la nueva Oficina Judicial operada por la Ley 13/2009, de 3 de noviembre, se ha atribuido su conocimiento a los Secretarios Judiciales, para que puedan llevar a cabo la labor mediadora que es propia de ella, dando de esta manera cumplimiento a lo previsto al respecto en el art. 456.3 c) LOPJ. Se trata, en nuestra opinión, de una opción adecuada puesto que, tal y como hemos señalado en el texto principal, en el acto de conciliación no se ejercita la potestad jurisdiccional de forma que el legislador tiene expedita la vía para atribuir su conocimiento y resolución a órganos judiciales distintos de los Jueces.

$3^{\circ}$ Esta solución, en palabras de AlCAlá-Zamora y CAstillo, N. (Proceso, autocomposición y autodefensa, UNAM, $3^{\text {a }}$ ed., México I99I, pp. 73-77), pasa porque las partes hagan dejación total o parcial de sus respectivas posiciones iniciales a través del desistimiento o la renuncia, del allanamiento o de la transacción.

${ }^{31}$ Cfr. MARTín Diz, F., La mediación: sistema complementario de Administración de Justicia, CGPJ, Madrid 20Io, p. 50. En igual sentido vid. SolETo MuÑoz, H., «La mediación: método de resolución alternativa de conflictos en el proceso civil español», en Revista Eletrônica de Direito Processual, núm. 3 (2009), p. 67.

${ }^{32}$ Con parecidos términos se define la mediación en el art. I de la Ley I5/2009, de 22 de julio, de mediación en el ámbito del Derecho privado de la Comunidad Autónoma de Cataluña: «se entiende por mediación el procedimiento no jurisdiccional de carácter voluntario y confidencial que se dirige a facilitar la comunicación entre las personas, para que gestionen por ellas mismas una solución a los conflictos que las afectan, con la asistencia de una persona mediadora que actúa de modo imparcial y neutral». Por último, cabe recordar igualmente la definición que de la mediación contiene el art. 6 de la Directiva 2008/52/CE, sobre ciertos aspectos de la mediación en asuntos civiles y mercantiles: «un procedimiento estructurado, sea cual sea su nombre o denominación, en el que dos o más partes en un litigio intentan voluntariamente alcanzar por sí mismas un acuerdo sobre la resolución de su litigio con la ayuda de un mediador (...) Incluye la mediación llevada a cabo por un juez que no sea responsable de ningún procedimiento judicial vinculado a dicho litigio. No incluye las gestiones para resolver el litigio que el órgano jurisdiccional o el juez competentes para conocer de él realicen en el curso del proceso judicial referente a ese litigio». 
voluntaria intentan alcanzar un acuerdo para la resolución de la controversia surgida entre ellas ${ }^{33}$.

Por lo que respecta a la naturaleza jurídica de la mediación, en una primera aproximación de lege lata, podría concluirse su naturaleza procesal e, incluso, jurisdiccional. En el primer caso porque la Disposición Final sexta del PLMed invoca los arts. I49.I.6 ${ }^{\mathrm{a}}$ y $8^{\mathrm{a}}$ CE como título competencial al amparo del cual se dicta ese Proyecto de Ley; es decir, la competencia exclusiva del Estado en materia de legislación mercantil, procesal y civil. Y en el segundo porque el art. 26 de PLMed confiere eficacia ejecutiva al acuerdo de mediación constituyendo (de haber entrado en vigor sin modificaciones en este punto el frustrado Proyecto ahora comentado) título suficiente para poder instar la ejecución forzosa en los términos previstos en la LEC- y la ejecución forzosa integra la función jurisdiccional que, como es sabido, no se agota exclusivamente en decir el Derecho en el caso concreto sino que también comprende, cuando es necesario, realizarlo (arg. ex art. II7.3 CE).

Las declaraciones explícitas e implícitas que lleva a cabo el PLMed sobre la naturaleza jurídica de la mediación nos parecen herradas, al menos por dos motivos. En primer lugar, porque no se puede conferir carácter ejecutivo al acuerdo de mediación, ya que ello sería tanto como conferir carácter jurisdiccional per se a un acuerdo -que no a una resolución- proveniente de una persona no investida de la potestad jurisdiccional; que, como es sabido, el art. II7.I y 3 CE reserva exclusivamente a Jueces y Magistrados. En segundo lugar porque, de conferirse carácter estrictamente procesal a la mediación (art. I49.I. $6^{a} \mathrm{CE}$ ), todas las leyes de mediación autonómicas serían inconstitucionales al carecer las Comunidades Autónomas de título competencial constitucional para poder dictarlas ${ }^{34}$. Como bien ha señalado BARONA VILAR «en el caso del procedimiento de mediación no estamos ante función jurisdiccional, ni debe estarse en ningún caso. La mediación comporta un mecanismo para desplegar una labor por un tercero, que no actúa heterocompositivamente o supra partes, sino que lo hace autocompositivamente o intra partes. No impone la decisión el mediador, como sí hace el juez al ejercer la función jurisdiccional, sino que trabaja con las partes, aproximándolas, ayudándolas a asentar sus posiciones e intereses, que no son siempre los mismos» ${ }^{35}$.

En otro orden de cosas, el Anteproyecto de Ley de Jurisdicción Voluntaria de 2005 (en adelante ALJV) ${ }^{36}$ incluía la mediación intrajudicial como un expediente más, y así fue reclamado por algunos Diputados durante la tramitación parlamentaria del Proyecto ${ }^{37}$. Los

33 Vid., al respecto, MARTín Diz, F., La mediación..., cit., p. 6o. En igual sentido se ha pronunciado, respecto de la mediación penal, BARONA VILAR, S., Mediación penal. Fundamento, Fines y régimen jurídico, tirant lo blanch, Valencia 20II, pp. 257-265

34 Ley 4/200I, de 3I de mayo, reguladora de la mediación familiar en Galicia; Ley 7/200I, de 26 de noviembre, reguladora de la mediación familiar, en el ámbito de la Comunidad Valenciana; Ley I5/2003, de 8 de abril, de la mediación familiar de Canarias; Ley 4/2005, de 24 de mayo, del Servicio Social Especializado de Mediación Familiar de Castilla- La Mancha; Ley I/2006, de 6 de abril, de Mediación Familiar en Castilla y León; Ley I/2007, de 2i de febrero, de Mediación Familiar de la Comunidad de Madrid; Ley del Principado de Asturias 3/2007, de 23 de marzo, de Mediación Familiar; Ley I/2008, de 8 de febrero, de Mediación Familiar del País Vasco; Ley I/2009, de 27 de febrero, reguladora de la Mediación Familiar en la Comunidad Autónoma de Andalucía; Ley 15/2009, de 22 de julio, de mediación en el ámbito del Derecho privado de Cataluña; Ley I4/20Io, de 9 de diciembre, de mediación familiar de las Illes Balears; y Ley I/20II, de 28 de marzo, de Mediación Familiar de Cantabria. Por su parte, en la actualidad la Comunidad Autónoma de Aragón se encuentran tramitando un Proyecto de Ley de mediación familiar.

${ }^{35}$ Cfr. Barona Vilar, S., Mediación penal, cit., p. 262.

${ }^{36}$ Cfr. «Anteproyecto de Ley de Jurisdicción Voluntaria», Boletín de Información, Ministerio de Justicia, Año LIX, Octubre de 2005

37 En efecto, la Ponencia de la Comisión General de Codificación encargada de redactar el Anteproyecto de Ley de Jurisdicción Voluntaria incluyó en ésta un capítulo (arts. 34 a 40) que regulaba la mediación. Dicha regulación desapareció del Proyecto de Ley que el Gobierno presentó al Congreso de los Diputados para su tramitación parlamentaria. Por ello, el Grupo Parlamentario Popular en el Congreso de los Diputados presentó las enmiendas número. 239 y 240 para incluir en el Título III de la ley un nuevo Capítulo II, con ocho artículos, 
arts. 34 a 40 ALJV regulaban un procedimiento de mediación previsto para cuando, en cualquier fase de los procedimientos judiciales, las partes solicitasen la suspensión del curso del litigio para intentar alcanzar un acuerdo contando con la actividad mediadora de un tercero. En tal caso el tribunal podría, de oficio y con suspensión del curso del proceso por un plazo máximo de tres meses a computar desde la efectiva designación del mediador, remitir a las partes a mediación, cuando, después de las alegaciones iniciales de las partes no hubiera sido posible lograr un acuerdo en el momento previsto legalmente para ello, y siempre que apreciara, en resolución motivada tras oír a las partes, que todavía era posible y conveniente conseguir una solución negociada, a través de la actuación del mediador. Nombrado el mediador, incluso por el propio tribunal cuando la mediación se hubiera acordado de oficio, éste asistiría a las partes en una negociación directa entre éstas con la finalidad de establecer la comunicación interrumpida como consecuencia del litigio y poder alcanzar de este modo un acuerdo de fondo sobre la controversia. Además, el art. 39 ALJV no confería eficacia ejecutiva al acuerdo de mediación. Simplemente se preveía que si las partes alcanzaban un acuerdo, total o parcial, durante la actividad mediadora se consignaría por escrito y se remitiría inmediatamente por el mediador al tribunal para que éste alzara la suspensión del proceso y, tras ser ratificado por las partes con asistencia de sus letrados y con audiencia del Ministerio Fiscal si resultare precisa, resolviera sobre la aprobación de dicho acuerdo. En el caso de que, o bien no se lograse el acuerdo en el plazo máximo conferido por el tribunal, o bien los acuerdos de mediación fueran sólo parciales en lo que correspondiese para resolver sobre el objeto litigioso subsiguiente, continuaría el proceso.

Al igual que en el caso del acto de conciliación, en nuestro criterio en la mediación no se ejerce la función jurisdiccional pero tampoco se puede conceptuar como un expediente de jurisdicción voluntaria. De una parte, en la mediación no concurren las notas características de la función jurisdiccional puesto que los sujetos acuden a ella de manera voluntaria (falta de pretensión) y el acuerdo de mediación no excluye la apertura de un proceso con idéntico objeto y sujetos (falta de cosa juzgada material) ${ }^{38}$. Además, la

que regulaba un procedimiento de mediación que tendría lugar cuando las partes de un proceso contencioso, en cualquier momento de su tramitación, solicitaran la suspensión del curso del litigio para intentar alcanzar un acuerdo con la actividad mediadora de un tercero. Finalmente, la propuesta de establecer un capítulo que regulara la mediación familiar en la futura Ley de Jurisdicción Voluntaria fue rechazada por la presentación de una proposición no de ley, presentada por el Grupo Parlamentario de Izquierda Unida-Iniciativa Per Catalunya Verds, sobre la creación de una ley de mediación familiar. Como expuso la Diputada del Grupo Parlamentario Popular, Dña. Ana Torme Pardo, al defender la enmienda de su Grupo: «en estos momentos se está tramitando otro proyecto de ley que ha remitido aquí el Gobierno, el proyecto de Ley en materia de jurisdicción voluntaria, y hay que tener en cuenta que la mediación sin duda es un procedimiento típico de jurisdicción voluntaria, un procedimiento de lo que al Ministro actual, el señor Fernández Bermejo, le gusta denominar como justicia preventiva, y es que es cierto que la mediación desde luego es un buen sistema para poder resolver conflictos entre las personas y de esta manera evitar litigios. Resulta curioso, a juicio del Grupo Parlamentario Popular, que cuando la Comisión de Codificación se encargó de elaborar el ALJV lo estudió, Comisión de Codificación constituida por expertos que fueron nombrados por consenso., estos consideraron que era necesario incluir la mediación dentro del articulado [arts. 34 a 40] del ALJV. En Anteproyecto de Ley estaba, y así se remitió a informe de los órganos oportunos, sin embargo, sin saber ni cómo ni porqué, el Gobierno lo quita del articulado y aprueba un proyecto de ley en el que ya desaparece la regulación de la mediación. Nosotros no lo entendemos y desde luego nos paree que no tiene ningún sentido, por eso presentábamos una enmienda en la que instábamos al Gobierno a que en la sucesiva tramitación parlamentaria pueda solicitar, por ejemplo, del grupo parlamentario que lo sustenta en el Senado que presente las enmiendas oportunas para que se recupere la mediación en el PLJV». Cfr. Diario de Sesiones del Congreso de los Diputados, VIII Legislatura, año 2007, núm. 872, Sesión núm. 49, p. 24.

$3^{8}$ Ello no obsta para que el acuerdo de mediación pueda alcanzar los efectos propios de la cosa juzgada formal que implica la imposibilidad de postular la anulación del acuerdo de mediación una vez transcurridos los plazos para solicitarla. No obstante, los apartados 4 y 5 del art. 24 PLMed podría hacer llegar a la conclusión contraria ya que dispone que el acuerdo de mediación produce efectos de cosa juzgada para las partes y frente a él sólo cabrá solicitar la anulación o la revisión conforme a lo establecido en la Ley de Enjuiciamiento Civil para las sentencias firmes. Ahora bien, estamos de acuerdo con LORCA NAVARRETE, A. M. (Informe sobre el Anteproyecto de Ley de Mediación en asuntos Civiles y Mercantiles, IVAP, Bilbao 20I0, p. I5I) cuando sostiene que «el 'acuerdo de mediación', ni es jurisdicción o producto de ella ni es una resolución jurisdiccional. En base a razones, exclusivamente, negociales, también, en la mediación, la cosa juzgada es el efecto que, produce el 'acuerdo de negociación' que no sólo lo resuelve, definitivamente, sino que, por ello, le atribuye firmeza (cosa juzgada 
mediación es atribuida a los mediadores ${ }^{39}$ y no a los Jueces y Magistrados, únicos sujetos jurídicos investidos constitucionalmente de la potestad jurisdiccional (art. II7.I y 3 CE). De otra parte, por definición la mediación supone la presencia de dos o más partes en conflicto, por lo que dogmáticamente no puede incluirse entre los expedientes de jurisdicción voluntaria, al incumplir uno de los caracteres esenciales de ésta: la ausencia de controversia. La mediación, en tanto que método auto-composición y no adversativo, descansa sobre el pilar de la igualdad de las partes ${ }^{40}$, quienes, de forma voluntaria ${ }^{4 \mathrm{I}}$, intentan alcanzar un acuerdo para la resolución de la controversia surgida entre ellas. La voluntariedad y libre decisión de las partes es consustancial a la mediación ${ }^{42}$, son ellas las encargadas de gestionar y tramitar el conflicto surgido de un determinado negocio jurídico y el mediador carece, en todo caso, de capacidad decisoria sobre el fondo de la situación conflictiva.

\section{Conciliación, mediación y jurisdicción voluntaria}

Como ya se ha dicho en los dos epígrafes precedentes, en nuestra opinión ni la conciliación ni la mediación pueden incluirse dentro de los expedientes de jurisdicción voluntaria; y ello a pesar de que así se ha pretendido tanto por la doctrina y la jurisprudencia, como por el legislador, especialmente respecto del acto de conciliación civil. El motivo de ello es común en ambos casos: tanto en la conciliación como en la mediación se verifica la existencia $a b$ initio de dos o más partes en un conflicto de intereses. Con independencia de que tanto a la conciliación como a la mediación se acuda voluntariamente y con la intención de que la resolución de la disputa se produzca a través del acuerdo de las partes, sin embargo, en ambos casos, la tercera persona (ya sea un Secretario Judicial o un mediador) se encuentra ante un conflicto entre partes determinadas, por lo que no cabe hablar en estos supuestos de expedientes de jurisdicción voluntaria. A dicha conclusión de puede llegar igualmente de la adecuada interpretación del art. 456.3 LOPJ puesto que, entre las competencias que se pueden atribuir legalmente a los Secretarios Judiciales, se distinguen las conciliaciones de la jurisdicción voluntaria; denotándose de este modo que son actividades jurídicas diversas.

formal ad intra) impidiendo su anulación o que, su contenido pueda ser reproducido, posteriormente, en una nueva mediación (cosa juzgada material ad extra)».

39 Es decir, personas que se hallen en el pleno disfrute de sus derechos civiles, carezcan de antecedentes penales por delito doloso, estén en posesión de título oficial universitario o de educación profesional superior, tengan suscrito un seguro de responsabilidad civil o garantía equivalente y figuren inscritas en el Registro de Mediadores y de instituciones de mediación del Ministerio de Justicia, de acuerdo con lo previsto en el art. I2 PLMed.

$4^{\circ}$ Para un excursus sobre los principios de la mediación vid., por todos, SASTRE Peláez, A. J., «Principios generales y definición de la mediación familiar: su reflejo en la legislación autonómica», en Diario La Ley, núm. 5478 (2002), pp. I-5; MARTín Diz, F., La mediación..., cit., pp. 69-86; García VillaluenGA, L., «La mediación a través de sus principios. Reflexiones a la luz del anteproyecto de ley de mediación en asuntos civiles y mercantiles», en Revista General de Legislación y Jurisprudencia, núm. 4 (20IO), pp. 7I7-756; BARONA VILAR, S., Mediación penal, cit., pp. 266-285. A partir del principio de la igualdad de partes, que se distingue como principio fundamental de la mediación, MARTín DIz, a quien seguimos en este punto, enumera otros siete principios: voluntariedad, oralidad, proximidad, inmediación y no sustitución de las partes (carácter personalísimo), confidencialidad, flexibilidad (informalidad) y probidad.

4I Como señala Martín Diz, F., La mediación..., cit., p. 73, nota 3I, «las partes han de ser totalmente libres para acudir a la mediación (...) Así lo respaldan jurisprudencialmente, entre otras, la Sentencia de la Audiencia Provincial de Cádiz de 25 de marzo de 2006 (la mediación familiar se ha revelado como un instrumento eficaz de solución de las discordias... si bien nunca puede ser impuesta, siendo la voluntariedad de su aceptación un requisito de aquélla) o el Auto de la Audiencia Provincial de Girona de 20 de junio de 2003 [JUR 2004\24069, $\mathrm{F} J 2^{\circ}$ ] (la mediación familiar ha de respetar el principio de autonomía de la voluntad de los litigantes... las partes no solamente son libres de acogerse o no a la mediación, sino también de desistir en cualquier momento)».

$4^{2}$ Ello ha llevado a LorCA NAVArrete, A. M. (Informe sobre el Anteproyecto de Ley de Mediación..., cit., p. I9) a afirmar que «la justificación constitucional de la Mediación se encuentra en el principio de la autonomía de la voluntad que consagra el art. I.I de la Constitución. No se justifica en el art. 24 de la Constitución». 
Porque tanto en la conciliación como en la mediación las partes tratan de gestionar un conflicto con la ayuda de un tercero, consideramos que ambas instituciones se engloban dentro de los sistemas alternativos de resolución de conflictos. De esta forma, se puede sostener que los ciudadanos tienen dos vías para resolver sus conflictos jurídicos: recurrir a la vía jurisdiccional o bien hacerlo a través de un sistema complementario de la Administración de Justicia (genéricamente conocido por sus siglas en inglés $A D R$ ) que, habiendo sido institucionalizado, incluye cuatro instrumentos ${ }^{43}$ : la transacción (arts. I809 a I8I9 CC) ${ }^{44}$, la conciliación (arts. 460 a 480 LEC/I88I), la mediación (PLMed) y el arbitraje (Ley 60/2003, de 23 de diciembre, de arbitraje) ${ }^{45}$. Ahora bien, conviene precisar que este sistema complementario de Administración de Justicia es alternativo al sistema judicial tradicional, pero en ningún caso lo puede llegar a excluir ${ }^{46}$ : todas estas alternativas de resolución de conflictos pueden y deben convivir de forma simultánea ya que no todos los conflictos son iguales, ni tienen la misma intensidad, por lo que, dependiendo del conflicto en cuestión, será conveniente recurrir a uno u otro sistema.

Frente a las dos posibles vías de resolución de conflictos (proceso jurisdiccional y $A D R$ ), la jurisdicción voluntaria es una institución procesal cuya finalidad no es la de resolver conflictos sino, antes al contrario, satisfacer los intereses jurídicos de los particulares, precisamente para la protección, con el debido «desinterés objetivo», de intereses preferentemente públicos como son la certeza de las relaciones jurídicas, la verificación de las condiciones exigidas legalmente o la tutela de las personas.

${ }^{43}$ Así, Blanco Carrasco, M., Mediación y sistemas alternativos de resolución de conflictos. Una visión jurídica, Reus, Madrid 2009, p. 9

${ }^{44}$ Como es sabido, el art. I8०9 CC define la transacción como el «contrato por el cual las partes, dando, prometiendo o reteniendo cada una alguna cosa, evitan la provocación de un pleito o ponen término al que había comenzado». De esta definición se desprende que son dos los presupuestos necesarios para que un contrato pueda calificarse de transacción: por una parte, una situación de controversia entre dos o más personas, y por otra, la necesidad de recíprocas concesiones entre ellas. Por otro lado, la transacción tanto puede poner fin al proceso que ya había comenzado como evitarlo: la controversia que lo dirime lo mismo puede haberse llevado ya ante los órganos jurisdiccionales (o a árbitros), como no haber llegado a esa fase. En cuanto a su naturaleza jurídica, la jurisprudencia ha declarado desde antiguo que toda transacción da lugar al nacimiento de nuevos vínculos u obligaciones, en sustitución de los extinguidos, o a su modificación [SSTS de 26 de abril de I963 (RJ I963\24I8), de 20 de abril de I989 (RJ I989\3244), de 29 de noviembre de I99I (RJ I99I \8575), 6 de noviembre de I993 (RJ I993\86I8), de 30 de julio de I996 (RJ I996।6079); y más modernamente SAP de Alicante de 2 de diciembre de 2002 (JUR 2003/73335), AAP de Guadalajara de I3 de julio de 2006 (JUR $2006 \backslash 224936)]$. Opera como si la relación anterior fuera firma y exacta, y entonces no hay duda de que la transacción, por su misma estructura (recíprocas concesiones), tiene que aportar una modificación o una sustitución que suponga la desaparición de la controversia.

45 Podemos definir el arbitraje, con Diez-Picazo Giménez (vid. De la Oliva Santos, A., Díez-Picazo GiméneZ, I. y Vegas Torres, J., Derecho procesal civil. Ejecución forzosa. Procesos especiales, EURA, $3^{\text {a }}$ ed., Madrid 2005, p. 609), como aquella institución consistente en que dos o más personas pacten entre sí que un tercero resuelva un litigio ya surgido o que pueda surgir entre ellas respecto de una determinada relación jurídica, contractual o no contractual, excluyendo que los Tribunales conozcan del mismo. El Tribunal Constitucional ha sostenido que su naturaleza jurídica es para-jurisdiccional o quasi-jurisdiccional [ATC 259/1993, de 20 de julio (RTC I993\259), $\mathrm{FJ} \mathrm{I}^{\circ}$ ], es decir, que es un «equivalente jurisdiccional» [STC 62/I99I, de 22 de marzo (RTC I99I $\backslash 62), F J 5^{\circ}$, de tal forma que se considera que es una institución de naturaleza contractual en su origen y jurisdiccional en sus efectos.

${ }^{46}$ Vid., en este sentido, la Recomendación 98/257/CE de la Comisión, de 30 de marzo, relativa a los principios aplicables a los órganos responsables de la solución extrajudicial de los litigios en materia de consumo (DOCE, L, II5, de I7 de abril de I998) que en su Considerando número 2i establece «...que los procedimientos extrajudiciales no pueden tener como objetivo sustituir al sistema judicial; que, por lo tanto, la utilización de la vía extrajudicial sólo puede privar al consumidor de su derecho de acceso a los tribunales si éste lo acepta expresamente, con pleno conocimiento de causa y con posterioridad al surgimiento del litigio»; Recomendación ésta tomada en cuenta precisamente en el Considerando número i8 de la Directiva 2008/52/CE del Parlamento Europeo y del Consejo, de 2I de mayo de 2008, sobre ciertos aspectos de la mediación en asuntos civiles y mercantiles (DOCE, L, I36, de 24 de mayo de 2008). Para un análisis de la significación de los métodos alternativos a la solución de litigios en el ámbito de la Unión Europea vid., por todos, Arias Rodríguez, J. M., «Reflexiones acerca de la Directiva 2008/53/CE sobre ciertos aspectos de la mediación en asuntos civiles y mercantiles», Revista del Poder Judicial, núm. 88 (2009), pp. I36-I42. 
Ahora bien, las dificultades surgen cuando se trata de establecer las fronteras entre la conciliación y la mediación. En este sentido consideramos que, a pesar de los encomiables esfuerzos doctrinales que se han realizado para diferenciar ambas figuras ${ }^{47}$, no es posible realizar una delimitación jurídica absoluta entre ellas ${ }^{48}$. De hecho, el art. 456 6.3.c LOPJ parece identificar ambas instituciones cuando prevé la posibilidad de atribuirle competencia a los Secretarios Judiciales en materia de «conciliaciones, llevando a cabo la labor mediadora que les sea propia». A pesar de ello sí cabe apuntar como diferencia, más formal que sustancial, que, mientras que en la mediación el tercero es un mediador, en la conciliación -tanto preprocesal (arts. 460 a 480 LEC/I88I) como intraprocesal (art. 4I5 LEC) - ha de ser en todo caso un órgano judicial: Secretario Judicial o Juez de Paz en el primer supuesto y Juez o Magistrado en el segundo. Precisamente por ello consideramos que, desde un punto de vista estrictamente dogmático, no cabe incluir el acto de conciliación entre los actos previos al proceso; máxime si se tiene en cuenta que desde la modificación operada por la Ley 34/1984, de 6 de agosto, de reforma urgente de la LEC/I88I, el acto de conciliación es voluntario para las partes en conflicto ${ }^{49}$, pudiendo éstas acudir directamente al proceso jurisdiccional sin que el Juez pueda oponer el que no se haya intentado la conciliación como fundamento de la inadmisibilidad de la demanda ${ }^{50}$.

\section{Valoración de algunas novedades en materia de conciliación y mediación}

Para concluir el presente trabajo cabe realizar unas breves reflexiones sobre dos de las novedades más significativas introducidas en el procedimiento de conciliación por la Ley 13/2009, de 3 de noviembre, de reforma de la legislación procesal para la implantación de la

${ }^{47}$ En este sentido merece la pena mencionar la distinción propuesta por BONET NAVARRo, A., «La ejecución de lo conciliado fuera del proceso civil», Revista General de Derecho Procesal, núm. 24 (20II), p. 5: en la conciliación el tercero sólo exhorta a conseguir una avenencia, sin imponer su decisión, mientras que en la mediación el tercero guía a las partes para que alcancen por sí un acuerdo, que también tenga fuerza de cosa juzgada y sea ejecutable. Vid., igualmente, Moreno CATENA V. y CorTÉs Domínguez, V., Introducción al Derecho Procesal, Tirant lo Blanch, Valencia 2005, p. 4I. Esta parece ser, asimismo la posición el legislador. Así, mientras que la función del conciliador no es otra que la de procurar avenir a las partes y, si no puede conseguirlo, dar por termino el acta sin avenencia (art. 47I LEC/I88I); sin embargo, el mediador facilitará la comunicación entre las partes y, velando porque dispongan de la información y el asesoramiento suficientes, desarrollará una conducta activa, tendente a lograr el acercamiento entre las partes (arts. I4.I y 2 PLMed).

${ }^{48}$ En igual sentido vid. SOLETO MuÑoz, H., «La mediación: método de resolución alternativa de conflictos en el proceso civil español», cit., pp. 68-70, quien además concluye que «en el Derecho comparado no existe una distinción absoluta entre mediación y conciliación; ambos términos pueden referirse a la intervención de un tercero para llegar a un acuerdo, así como a la propia posibilidad de un acuerdo entre las partes. En general, en los sistemas anglosajones, la conciliación engloba a la mediación, y, por otra parte, se considera que la actividad de conciliación es más intervencionista» (op. cit., p. 69).

49 En el Derecho español tradicionalmente la regla era la contraria. El acto de conciliación era preceptivo. Se precisaba haberlo intentado antes de poder interponer una demanda. El carácter preceptivo de la conciliación estuvo vigente en nuestro régimen constitucional desde I8I2 y acabó por ser invertido por la Ley 34/i984, de 6 de agosto, de reforma urgente de la Ley de Enjuiciamiento Civil de i88I. Este cambio sustancial en el régimen jurídico de la conciliación se produjo porque se tomó consciencia de que «en la mayoría de los casos el acto de conciliación era inútil, porque si las partes estaban dispuestas a llegar a un acuerdo lo alcanzaban privadamente, y en caso contrario el litigio era inevitable». Este razonamiento es sostenido por DiEZ-PICAZo GIMÉNEZ, I. (con De la Oliva Santos, A.), Derecho procesal civil, cit., p. 23I. Igualmente, vid. MoReno Catena, V. (con CoRTÉS DomíngueZ, V. y Gimeno Sendra, V.), Derecho procesal civil, cit., pp. I64-I65.

$5^{\circ}$ Ello no obstante, como han puesto de manifiesto respecto de la conciliación laboral previa (arts. 63 a 68 ljS) Monereo Pérez, J. L., Molina Navarrete, C., Moreno Vida, M. N., Olarte Encabo, S. y Fernández Avilés, J. A. (Manual de Derecho procesal del trabajo, cit., pp. I34-I35), «la doctrina constitucional ha considerado compatible [la exigencia del intento de la conciliación laboral previa al proceso] con el derecho a la tutela judicial efectiva (art. 24.I CE), porque la imposición de dicho trámite no excluye el conocimiento jurisdiccional de la cuestión controvertida, al suponer simplemente un aplazamiento de la intervención judicial y sin que se trate de un trámite desproporcionado o injustificado, al procurar una solución extraprocesal de la controversia que beneficia tanto a las partes como al sistema judicial (SSTC 75/200I, de 26 de marzo [RTC 200I|76]; 207/I99I, de 4 de noviembre [RTC I99I $\backslash 207]) »$. 
nueva Oficina judicial, así como dos de las propuestas planteadas en materia de mediación por el frustrado PLMed: quiénes pueden conocer de la conciliación y la mediación y los efectos procesales derivados del acto de conciliación y del procedimiento de mediación.

Hemos de comenzar apuntando que la reforma de la conciliación civil de 2009 (y, sólo en una parte, la procesal laboral) es deudora en sus dos aspectos más importantes atribución de su conocimiento a los Secretarios Judiciales (art. 460 LEC/I88I) y fuerza ejecutiva de lo convenido en conciliación (arts. 476 LEC/I88I y 68.I LJS)- del PLJV de $2007^{5 \mathrm{I}}$, en donde, de forma clara, ya venía a reconocerse que el órgano judicial se limita a convalidar la expresión de la voluntad de los intervinientes. Por su parte, en materia de mediación, el malogrado PLMed de 20II incorporaba al Derecho español la Directiva 2008/52/CE, sobre ciertos aspectos de la mediación en asuntos civiles y mercantiles, si bien su regulación iba más allá del contenido de ésta, de tal forma que, según señalaba, conformaba «un régimen general aplicable a toda mediación que tenga lugar en España, y pretenda tener un régimen jurídico vinculante, si bien circunscrita al ámbito de los asuntos civiles y mercantiles» (Apartado III de su Exposición de Motivos). En lo que ahora nos interesa, dicho Proyecto de Ley regulaba tanto el estatuto del mediador (arts. I2 a I6) ${ }^{52}$ como la fuerza ejecutiva de los acuerdos de mediación (arts. 26 a 29) (53 $^{53}$

\section{VI.I. Profesionales competentes para conocer de la conciliación y la mediación}

Aunque dogmáticamente no cabe incluirlo entre los expedientes de jurisdicción voluntaria, la conciliación civil tampoco puede conceptuarse como un proceso jurisdiccional stricto sensu por lo que, en nuestra opinión, no resulta violento atribuir su conocimiento a unos funcionarios expertos en Derecho procesal como son los Secretarios Judiciales; máxime si se tiene en cuenta la finalidad que perseguían tanto la reforma de la legislación procesal de 2009 como el propio PLJV de 2007: descargar a los Jueces y Magistrados de todas aquellas responsabilidades y funciones que no tienen carácter jurisdiccional; que es a lo que, al menos en teoría, tiende el nuevo modelo de la oficina judicial.

${ }^{51}$ Se debe poner de manifiesto, a este respecto, que en este concreto punto el redactor del Proyecto de Ley de Jurisdicción Voluntaria de 2007 siguió a pies juntillas la regulación existente, previa a la reforma de 2009 , contenida en los arts. 460 a 480 LEC/I88I, incurriendo con ello en una deficiente técnica legislativa. Y ello por dos razones: de una parte, porque el Título III del PLJV de 2007 redundaba innecesariamente en una serie de cuestiones -como son la competencia o los datos, circunstancias y cuestiones a consignar en la solicitud- que ya se hallaban reguladas con carácter general y con una mejor sistemática en otras partes de dicho texto articulado; de otra parte, porque al seguirse tan fielmente algunos de los preceptos reguladores de la conciliación en la LEC/188I (entre otros su art. 477, que tampoco ha sido modificado en la reforma de 2009), se perdió la oportunidad de consolidar definitivamente la doctrina del Tribunal Supremo en torno a la acción de nulidad contra lo convenido en acto de conciliación

$5^{2}$ Cabe recordar, a este respecto, que el art. 3 de la Directiva 2008/52/CE del Parlamento Europeo y del Consejo, de 2I de mayo de 2008 , sobre ciertos aspectos de la mediación en asuntos civiles y mercantiles (DOCE, L, I36, de 24 de mayo de 2008) define como mediador a «todo tercero a quien se pida que lleve a cabo una mediación de forma eficaz, imparcial y competente, independientemente de su denominación o profesión en el Estado miembro en cuestión y del modo en que haya sido designado o se le haya solicitado que lleve a cabo la mediación».

53 También el art. 6 de la Directiva 2008/52/CE establece que: «I. Los Estados miembros asegurarán que las partes, o una de ellas con el consentimiento explícito de las otras, puedan solicitar que el contenido de un acuerdo por escrito resultante de una mediación sea hecho ejecutivo, en la medida en que el contenido del acuerdo pueda ser ejecutivo con arreglo al Derecho del Estado miembro donde se formule la solicitud y ello no sea contrario al mismo. 2. El contenido de un acuerdo puede ser hecho ejecutivo mediante una sentencia, una decisión o un acto auténtico emanado de un órgano jurisdiccional o cualquier otra autoridad competente de conformidad con la legislación del Estado miembro en el que se formula la solicitud». Ahora bien, la regulación del carácter ejecutivo de los acuerdos resultantes de mediación prevista por esta Directiva «presentan notables diferencias, especialmente al no establecerse disposición alguna para asegurar que el acuerdo alcanzado en el procedimiento de mediación sea esencial para que las mismas estén dispuestas a cumplirlo». Cfr. ARIAS RodRÍGUEZ, J. M., «Reflexiones acerca de la Directiva...», cit., pp. I68-i69. 
De igual forma, aunque estamos de acuerdo con MARTín DIZ en que «jurisdicción y mediación (...) son soluciones complementarias y alternativas, la idiosincrasia de cada una de ellas es muy diferente, y por tanto el juez no puede intervenir como mediador, con tal calidad y atribuciones en ningún conflicto que se dirima mediante esta opción ${ }^{54}$; sin embargo, nada obstaría, desde un punto de vista dogmático, para que el conocimiento de los asuntos de mediación civil y mercantil fuera atribuido a los Jueces y Magistrados, siempre que dicha atribución fuera hecha por Ley en garantía de cualquier derecho (arg. ex art. II7.4 CE). Ahora bien, puesto que la reforma de la justicia y la agilización procesal pasan, también en nuestra opinión, por descargar a los Jueces y Magistrados de todas aquellas responsabilidades y funciones que no tienen carácter jurisdiccional, resulta coherente que el PLMed no atribuyera competencia en esta materia a los Jueces y Magistrados. Por el contrario, el art. I3 del Anteproyecto de Ley de Mediación ${ }^{55}$, que finalmente no se ha recogió en el Proyecto, parecía configurar al mediador de acuerdo con la definición ofrecida por MARTín DIZ: «un profesional liberal, de corte eminentemente jurídico, cuyo ejercicio y función consiste en la aproximación, ayuda y colaboración con las partes que recurren a él para solventar un conflicto o litigio a través de una mediación, sin imponer en ningún caso medidas concretas ni la solución del asunto» ${ }^{6}$. Además, a pesar de la práctica identidad dogmática de conciliación y mediación, de acuerdo con nuestra legislación procesal orgánica no cabe sostener la posibilidad de que los Secretarios Judiciales puedan actuar como mediadores puesto que el art. 456.3 LOPJ no dispone expresamente su competencia sobre dicha materia y el PLMed tampoco lo preveía (art. $456.3 . \mathrm{d}$ LOPJ) $)^{57}$.

\section{VI.2 Eficacia de las resoluciones de conciliación y mediación}

Como ya se ha sostenido, al conceptuarse como títulos ejecutivos se están equiparando el decreto que pone fin a un acto de conciliación y el acuerdo de mediación con la sentencia o a un auto judicial ejecutable. La fuerza ejecutiva de lo convenido por las partes en conciliación, tal y como disponía el art. 39.I PLJV y que tras la reforma de 2009 prevé ahora el art. $476 \mathrm{LEC/I88I}$, se ha impuesto por una cuestión práctica: la voluntariedad que caracteriza la conciliación necesita igualmente de la posibilidad real de lograr el cumplimiento y realización forzosa del acuerdo para que ésta no quede en papel mojado. De esta forma, su viabilidad como sistema auto-compositivo contractual de resolución de controversias, alternativo a la vía jurisdiccional, resulta harto improbable. Como acertadamente ha resumido BONET NAVARRO, «el legislador trata de ofrecer el acto de conciliación como un instrumento alternativo eficaz para la solución de conflictos con todas sus consecuencias $»^{58}$. Ahora bien, debe ponerse de manifiesto que lo que se ejecuta es la resolución que aprueba $u$ homologa (arts. I9.2 y 5I7.2. $3^{\circ}$ LEC) el acuerdo alcanzado por las partes en el acto de conciliación; es decir, el decreto del Secretario judicial o el auto del Juez de Paz, y no el acta en que consta lo convenido.

54 Cfr. MARTín Diz, F., La mediación..., cit., p. 2io.

55 Se entiende por mediador aquella persona inscrita como tal en el Registro de mediadores y de instituciones de mediación del Ministerio de Justicia, a quien se solicite que preste sus servicios para llevar a cabo una mediación de forma eficaz, imparcial, neutral y competente, con respeto al principio de confidencialidad.

${ }^{6}$ Vid. MARTín Diz, F., La mediación..., cit., p.I75. De acuerdo con el art. I2.d) PLMed es preceptivo que el mediador se inscriba en el Registro de mediadores de instituciones de mediación del Ministerio de Justicia.

57 Recuérdese, en este sentido, que el art. 63 LJS establece como órganos competentes para conocer de la conciliación o mediación laboral previa al Instituto de Mediación Arbitraje y Conciliación correspondiente o al órgano que asuma estas funciones, que podrá constituirse mediante los acuerdos interprofesionales o los convenios colectivos a los que se refiere el art. 83 del Texto Refundido de la Ley del Estatuto de los Trabajadores, así como mediante los acuerdos de interés profesional a los que se refieren el art. I3 y el apartado i del art. I8 de la Ley del Estatuto del trabajo autónomo.

${ }^{8}$ Cfr. Bonet Navarro, A., «La ejecución de lo conciliado fuera del proceso civil», cit., p. 5. 
Por lo que respecta a la competencia funcional para llevar a cabo la ejecución, ésta corresponderá «al mismo Juzgado en que se tramitó la conciliación, cuando se trate de asuntos de la competencia del propio Juzgado» (art. 476 LEC/I88I). Así, en los supuestos en que conozca el Secretario judicial del Juzgado de Primera Instancia o del Juzgado de lo Mercantil, el decreto que aprueba lo acordado por las partes en conciliación tendrá aparejada ejecución, llevándose a efecto en el mismo Juzgado en que se tramitó. Por su parte, el Juez de Paz sólo podrá realizar directamente la ejecución cuando el auto que aprueba el convenio de conciliación alcanzado ante él no supere los noventa euros, ya que ese es el límite de su competencia objetiva por razón de la cuantía para conocer de un pleito (art. 47 LEC); es decir, prácticamente nunca. Con carácter general, sin embargo, la ejecución del auto aprobador del convenio de conciliación obtenido ante el Juez de Paz, cuyo interés económico sea superior a noventa euros, corresponderá al Juzgado a quien hubiere correspondido conocer de la demanda, por razón de la cuantía, de la materia y del territorio ${ }^{59}$. Como claramente pone de manifiesto BONET NAVARRO, «la nueva regulación de la conciliación anterior al proceso presenta una novedad consistente en que todo lo convenido en ella es susceptible de fundamentar una pretensión ejecutiva, abandonándose aquella diversificación que existía antes de la reforma en la LEC/I88I, al atribuir fuerza ejecutiva sólo a lo convenido en la conciliación ante un Juez que tenga competencia para conocer de procesos de declaración que, por razón de la cuantía, o por razón de la materia podrían tramitarse ante él» ${ }^{60}$.

De igual manera, la ejecución de los acuerdos de mediación quedaba integrado en el sistema del enjuiciamiento civil acerca de los títulos ejecutivos ${ }^{6 \mathrm{I}}$, ya que éstos se configuraban como un «título suficiente para instar la ejecución forzosa en los términos previstos en la LEC» (art. 26 PLMed). Ahora bien, al igual que ocurre con la conciliación, tampoco aquí se ejecutaba el acuerdo alcanzado por las partes en la mediación, sino la resolución que lo aprueba $u$ homologa, de tal manera que no hubiera cabido que el mediador pudiera ejecutar directamente el acuerdo; si se trataba de una mediación intrajudicial, la ejecución de los acuerdos en ella alcanzados se instaría ante el tribunal que homologó el acuerdo; mientras que si se trataba de mediaciones extraprocesales, sería competente el Juzgado de Primera Instancia del lugar en que se hubiera firmado el acuerdo de mediación, de manera análoga a lo previsto en el art. 545.2 LEC para los laudos arbitrales (art. 27 PLMed).

Aunque es cierto que la tramitación parlamentaria del PLMed concluyó sin su efectiva promulgación como texto normativo ${ }^{62}$, la Ley $13 / 2009$, de 3 de noviembre, de reforma de la legislación procesal para la implantación de la nueva Oficina judicial introdujo sin embargo una regulación prácticamente idéntica a la prevista con carácter general en dicho proyecto de ley nonato respecto de la eficacia procesal del acuerdo de conciliación laboral previa y de mediación laboral, al modificar el art. 68.I LPL. Esta modificación ha sido incorporada a la vigente LJS, de tal forma que su art. 68. I dispone que «lo acordado en conciliación [previa laboral] o en mediación [laboral] constituirá título para

59 En este sentido, resultan tremendamente ilustrativas las reflexiones sobre las dificultades para determinar definitivamente el órgano ejecutor del auto del Juez de Paz en estos supuestos realizadas por BonET NAVARRO, A., «La ejecución de lo conciliado fuera del proceso civil», cit., pp. 20-22; a las que remitimos al lector, y cuya conclusión final es que «salvo que concurra el lugar del domicilio del demandado, o, en su caso, del demandante (fuero de la tramitación del acto de conciliación) con alguno de los lugares o domicilios idóneos que hubiera correspondido para formular la demanda, la ejecución no se atribuirá al Juzgado de Primera Instancia del partido en que se halle el Juez de Paz conciliador».

${ }^{60}$ Así, Bonet Navarro, A., «La ejecución de lo conciliado fuera del proceso civil», cit., p. 9.

${ }^{6}$ Vid. LorCA NAVARRETE, A. M., Informe sobre el Anteproyecto de Ley de Mediación..., cit., p. I57-I58.

${ }^{62}$ En efecto, el 2I de septiembre de 20II La Mesa de la Cámara acordaba ampliar el plazo de presentación de enmiendas al PLMed hasta el día 27 de septiembre de 20II; día en que, como es sabido, el Boletín Oficial del Estado publicó el Real Decreto I329/20II, de 26 de septiembre, de disolución del Congreso de los Diputados y del Senado y de convocatoria de elecciones. 
iniciar acciones ejecutivas sin necesidad de ratificación ante el juez o tribunal, y podrá llevarse a efecto por los trámites previstos en el Libro IV de esta Ley». En este sentido, el art. 237 LJS, que resulta aplicable a los acuerdos de conciliación y mediación, dispone que «las sentencias firmes y demás títulos, judiciales o extrajudiciales, a los que la presente Ley otorga eficacia para iniciar directamente un proceso de ejecución, se llevarán a efecto en la forma establecida en la LEC para la ejecución de sentencias y títulos constituidos con intervención judicial, con las especialidades previstas en esta Ley», siendo que «la ejecución se llevará a efecto por el órgano judicial que hubiere conocido del asunto en instancia, incluido el supuesto de resoluciones que aprueben $u$ homologuen transacciones judiciales, acuerdos de mediación y acuerdos logrados en el proceso. Cuando en la constitución del título no hubiere mediado intervención judicial [como ocurre en la conciliación laboral previa], será competente el juzgado en cuya circunscripción se hubiere constituido». Como se observa, en el ámbito de la jurisdicción social tampoco se ejecuta el acuerdo alcanzado por las partes en la conciliación o mediación, sino la resolución que lo aprueba u homologa, de tal forma que no cabe que el mediador pudiera ejecutar directamente el acuerdo. En cuanto al órgano competente para ejecutar dichas resoluciones, será o bien el juzgado o tribunal de instancia, para conciliaciones y mediaciones intraprocesales, o bien el Juzgado o Tribunal en cuya circunscripción se hubiere constituido para la conciliación laboral previa o la mediación laboral extraprocesal.

En conclusión de lo expuesto, el legislador español ha preferido imponer la solución pragmática a la dogmática y, así, se puede decir que tanto la conciliación civil (arts. 460 a 480 LEC/I88I) como la mediación (tal y como se preveía en el PLMed y en los arts. 63 a 68 LJS) se configuran, a semejanza del arbitraje, como una suerte de institución de naturaleza contractual en su origen y jurisdiccional en sus efectos. 